\title{
ASPEK HUKUM TERHADAP PENYELESAIAN SENGKETA BATAS WILAYAH DESA SENDI DI KABUPATEN MOJOKERTO
}

\author{
Indra Naufal Riza, Isnin Harianti, Suyatno, M. Zamroni \\ Universitas Maarif Hasyim Latif \\ Indra_naufal_riza@student.umaha.ac.id
}

Abstract :

Studi ini bertujuan meneliti penyelesaian perselisihan yang disediakan dalam sistem hukum Indonesia dan peran pemerintah dalam menyelesaikan sengketa perbatasan. studi ini mengunakan yuridis-empiris. Studi ini menyimpulkan bahwa; Pertama, sengketa tanah batas wilayah desa Sendi telah dipicu oleh krn agresi militer belanda, yg menyebabkan warga sendi meninggalkan wilayah sendi untuk mengungsi. Karena terjadi kekosongan tersebut, perhutan mengklaim itu miliknya. Dgn pembuktian jual beli uang golden dgn kepala desa yg dulu. Sekitar th 1998, warga keturunan sendi, menghendaki kembalinya desa Sendi. Kedua, paradigma penyelesaian sengketa batas umumnya melalui dua cara; resolusi sengketa perbatasan nonhukum, dan penyelesaian hukum. Dalam resolusi non-hukum, ini dimediasi oleh Kemendagri dan Pemerintah; sementara, dalam penyelesaian sengketa hukum itu dicapai melalui peninjauan kembali ke Mahkamah Agung atau Mahkamah Konstitusi. Ketiga, dalam sengketa batas wilayah, peran kasus sengketa adalah pemerintah. Hasil studi menunjukkan bahwa desa adat menjadi salah satu solusi untuk dapat mengakhiri sengketa desa Sendi antara penduduk Desa dengan Perhutani.

Kata Kunci : Aspek hukum, Sengketa batas wilayah, desa adat, desa sendi

\section{PENDAHULUAN}

Sebagaimana yang tercantum dalam Pasal 33 ayat (3) Undang-Undang Dasar Negara Republik Indonesia yang menyebutkan bahwa Tanah adalah kekayaan nasional yang dikuasai oleh Negara untuk dapat dipergunakan sebesarbesarnya kemakmuran rakyat ${ }^{1}$. Penguasaan atas tanah yang dilakukan oleh Negara ini lebih lanjut dituangkan dalam Undang-Undang Nomor 5 Tahun 1960 tentang Peraturan Dasar Pokok-Pokok Agraria dan undang-undang lainnya, UndangUndang nomor 11 tahun 1967, dan Undang-Undang Nomor 5 tahun 1967.

Dalam Pasal 2 Undang-Undang Undang-Undang Nomor 5 Tahun 1960 tentang Peraturan Dasar Pokok-Pokok Agraria menyebutkan 2:

(1) Atas dasar ketentuan dalam Pasal 33 ayat 3 Undang-Undang Dasar dan halhal sebagai yang dimaksud dalam pasal 1, Bumi, air, dan ruang angkasa,

1 PRESIDEN REPUBLIK Indonesia and Presiden Republik Indonesia, Undang-Undang No. 5 Tahun 1960 Tentang Peraturan Dasar Pokok-Pokok Agraria (Ganung Lawu, 1960).

2 Undang-Undang Nomor, "Tahun 1960 Tentang Peraturan Dasar Pokok-Pokok Agraria," Jakarta: portal. djmbp. esdm. go. id (diunduh 4 Nopember 2011) (5AD). 
ternasuk kekayaan alam yang terkandung di dalamnya itu pada tingkatan tertinggi dikuasai oleh Negara, sebagai organisasi kekuasaan seluruh rakyat.

(2) Hak menguasai dari Negara termaksud dalam ayat (1) pasal ini memberi wewenang untuk:

a. Mengatur dan menyelenggarakan peruntukan, penggunaan, perserdiaan dan pemeliharaan bumi air dan ruang angkasa tersebut;

b. Menentukan dan mengatur hubungan-hubungan hukum antara orang-orang dengan bumi air dan ruang angkasa;

c. Menentukan dan mengatur hubungan-hubungan hukum antara orang-orang dan perbuatan hukum yang mengenai bumi, air, dan ruang angkasa.

(3) Wewenang yang bersumber pada hak menguasai dari Negara tersebut pada ayat 2 pasal ini digunakan untuk mencapai sebesar-sebesar kemakmuran rakyat dalam arti kebangsaan, kesejahteraan dan kemerdekaan dalam masyarakat dan Negara hukum Indonesia yang merdeka, berdaulat, adil dan makmur.

(4) Hak menguasai dari Negara tersebut di atas pelaksanaannya dapat dikuasakan kepada daerah-daeah swatantra dan masyarakat-masyarakat hukum adat, sekedar diperlukan dan tidak bertentangan dengan kepentingan nasional, menurut Ketentuan-ketentuan Peraturan Pemerintah.

Hubungan hukum antara orang-orang dan perbuatan hukum mengenai bumi, air, dan ruang angkasa selalu menyita perhatian, untuk kemudian sifat dari hubungan tersebut berkembang dan mempengaruhi ekonomi, sosial, dan politik.

Menurut Soetomo, dalam bukunya, Politik dan Administrasi Agraria, menyebutkan, "Kuatnya sistem penguasaan tanah menurut adat merupakan sistem penguasaan tanah oleh masyarakat hukum adat yang merupakan cerminan dari sistem budaya dan perekonomian tradisional yang hidup di Indonesia",3. Hal ini terbukti dalam kemyatannya, sebagian besar wilayah di Indonesia, dikuasai oleh masyarakat hukum adat, sepanjang tidak bertentangan dengan peraturan perundang-undangan yang berlaku.

3 Soetomo, Politik Dan Administrasi Di Bidang Kebudayaan, Universitas Brawijaya, Fakultas Hukum, 1985). 
Lebih lanjut, Soetomo, dalam bukunya tersebut juga menerangkan bahwa, "Sistem penguasaan yang khas milik Indonesia kemudian berkembang dalam kebiasaan sehari-hari yang akhirnya diakui dan ditaati sebagai hukum yang berlaku dan dikenal dengan nama HUKUM ADAT."

Penguasaan tanah dengan menggunakan hukum adat, secara tegas, dapat dikaji dalam Pasal 5 Undang-Undang Nomor 5 Tahun 1960 tentang Peraturan Dasar Pokok-Pokok Agraria, yaitu: "Hukum agraria yang berlaku atas bumi, air, dan ruang angkasa ialah Hukum Adat, sepanjang tidak bertentangan dengan kepentingan nasional dan Negara, yang berdasarkan atas persatuan bangsa, dengan sosialisme Indonesia serta dengan peraturan-peraturan yang tercantum dalam Undang-Undang ini dan dengan peraturan perundang-undangan lainnya, segala sesuatu dengan mengindahkan unsur-unsur yang bersandar pada hukum agama. ${ }^{5,}$

Dalam Pasal 5 Undang-undang nomor 41 tahun 1999 tentang Kehutanan, menyebutkan:

1. Hutan berdasarkan atas statusnya terdiri dari:

a. Hutan Negara; dan

b. Hutan Hak

2. Hutan negara sebagaimana dimaksud pada ayat (1) huruf a, dapat berupa hutan adat.

3. Pemerintah menetapkan status hutan sebagaimana dimaksud pada ayat 1 dan 2; dan hutan adat ditetapkan sepanjang menurut kenyataannya masyarakat hukum adat yang bersangkutan masih ada dan diakui keberadaannya.

4. Apabila perkembangannya masyarakat hukum adat yang bersangkutan tiadak ada lagi, maka hak pengelolaan hutan adat kembali pada Pemerintah.

4 R Yando Zakaria, "Strategi Pengakuan Dan Perlindungan Hak-Hak Masyarakat (Hukum) Adat: Sebuah Pendekatan Sosio-Antropologis," BHUMI: Jurnal Agraria dan Pertanahan 2, no. 2 (2018): $133-150$.

5 Indonesia and Indonesia, Undang-Undang No. 5 Tahun 1960 Tentang Peraturan Dasar Pokok-Pokok Agraria. 
Dengan juga dengan Pasal 1 ayat 6 Undang-undang nomor 41 tahun 1999 tentang Kehutanan, menyebutkan: "Hutan adat adalah hutan negara yang berada dalam wilayah masyarakat hukum adat ${ }^{6} . "$

Masyarakat Hukum adat sendiri lebih lanjut diterangkan dalam Pasal 67 Undang-undang nomor 41 tahun 1999 tentang Kehutanan, yaitu:

1. Masyarakat hukum adat sepanjang menurut kenyataannya masih ada dan diakui keberadaannya berhak :

a. Melakukan pemungutan hasil hutan untuk pemenuhan kebutuhan hidup sehari-hari masyarakat adat yang bersangkutan;

b. Melakukan kegiatan pengelolaan hutan berdasarkan hukum adatyang berlaku dan tidak bertentangan dengan undang-undang; dan

c. Mendapatkan pemberdayaan dalam rangka meningkatkan kesejahteraannya.

2. Pengukuhan keberadaan dan hapusnya masyarakat hukum adat sebagaimana dimaksud pada ayat 1 ditetapkan dengan Peraturan Daerah.

3. Ketentuan lebih lanjut sebagaimana dimaksud pada ayat 1 dan 2 disatur dalam Peraturan Pemerintah.

Hutan adat yang dijadikan sebagai bagian dari Hutan Negara dapat menyamarkan keberadaan Hutan Adat itu sendiri, karena Negara dapat dengan mudah dan secara bebas mengambil alih hutan adat untuk kepentingan tertentu ${ }^{7}$.

Abdul Muis Yusuf dan Mohammad Taufik Mekoro, dalam bukunya berjudul: "Hukum Kehutanan di Indonesia," menjelaskan bahwa "Tanah Negara bukanlah tanah yang dimiliki oleh Negara, tetapi tanah yang dikuasai dan diurus oleh negara, dan Negara memberikan kesempatan kepada warga negaranya untuk menguasai. Asal konsep tanah negara itu adalah negara bukan pemilik, tetapi hanya mengatur dan menjaga.",

Atas dasar beberapa ketentuan di atas, Kelompok masyarakat Hukum Adat yang menyebut diri mereka dalam Aliansi Masyarakat Adat Nusantara (AMAN),

6 Undang-Undang Nomor, “Tahun 1999 Tentang Kehutanan,” Penerbit PT. Mitra Info, Jakarta (41AD).

7 Noer Fauzi Rachman, "Masyarakat Hukum Adat Adalah Bukan Penyandang Hak, Bukan Subjek Hukum, Dan Bukan Pemilik Wilayah Adatnya," Wacana 33 (2014): 25-50.

8 Abdul Muis Yusuf and Muhammad Taufik Makarao, Hukum Kehutanan Di Indonesia (Rineka Cipta, 2011). 
Kesatuan Masyarakat Hukum Adat Kenegerian Kuntu Kabupaten Kampar Provinsi Riau, dan Kesatuan Masyarakat Hukum Adat Kasepuhan Cisitu Kabupaten Lebak Provinsi Banten, mengajukan gugatan uji materi Pasal-pasal tersebut di atas ke Mahkamah Konstitusi yang telah memiliki kekuatan hukum tetap (final dan mengikat) dengan mengabulkan gugatan pemohon sebagian dalam Keputusan MK Nomor 35/PUU-X/2012 tanggal 26 Maret 2013 sehingga hutan adat mendapat kedudukan yang kuat kembali ${ }^{9}$.

Hal serupa telah dilakukan oleh masyarakat adat desa Sendi, Kecamatan Pacet, Kabupaten Mojokerto. Mereka yang tergabung dalam Forum Perjuangan Rakyat menceritakan bahwa Sendi adalah sebuah Desa yang terletak di kaki Gunung Welirang, sekitar \pm 80 MDPL. Wilayah Sendi merupaka wilayah subur yang dikelilingi oleh potensi alam berupa sumber mata air dan kawasan hutan. Masyarakat Sendi menggantungkan kehidupan mereka dari hasil pertanian dan perhutanan di wilayah hutan Sendi.

Hingga pada akhirnya, Pemerintah Hindia Belanda merampas wilayah Sendi tersebut melalui Boschweezen (Jawatan Kehutanan Belanda) untuk dijadikan Perkebunan Serai. Sebuah catatan yang dibuat oleh Adib Dian Mahmudi, yang ditunjukkan oleh Kepala Desa Persiapan Adat Desa Sendi, Pak Cip, begitu biasanya Beliau dipanggil, menjelaskan bahwa Pemerintah Hindia Belanda merampas dengan dalih ganti rugi dan tukar menukar. Hal tersebut sebagaimana dibuktikan dengan Berita Acara Nomor 3 tahun 1932 tanggal 10 Oktober 1932 tentang tukar menukar (Ruislag) dan ganti rugi dari Warga Desa Sendi, Kecamatan Pacet, Kabupaten Mojokerto kepada Boschweezen, dengan luas tanah yang dibebaskan seluas $\pm 72,55 \mathrm{Ha}$, kemudian Berita Acara Tata Batas tanggal 27 Maret 1935 ditetapkan bahwa Desa Sendi menjadi Kawasan Hutan Pegunungan Anjasmoro dan disahkan pada tanggal 23 Agustus 1935 oleh Inspektur Kepala Jawatan Kehutanan Belanda di Bogor.

9 Daisyta Mega Sari and Akhyaroni Fu'adah, "Peran Pemerintah Daerah Terhadap Perlindungan Hutan Adat Pasca Putusan Mahkamah Konstitusi Nomor 35/Puu-x/2012," Jurnal Penelitian HukumFakultas Hukum Universitas Gadjah Mada 1, no. 1 (2014): 53-61. 
Peraturan Menteri Dalam Negeri (Permendagri) Nomor 56 Tahun 2015 tentang Kode dan Data Wilayah Administrasi Pemerintahan, nama Sendi tidak lagi termasuk dalam 299 desa dan 5 Kelurahan di Kabupaten Mojokerto. Hal ini yang memicu terjadinya perjuangan Masyarakat desa Sendi yang menginginkan Sendi kembali menjadi sebuah desa, sebagaimana terbukti dengan adanya makam para leluhur Desa Sendi yang kini terawat. Sehingga hak atas penguasaan masyarakat desa adat dikebiri bahkan dihapuskan, sehingga Perhutani, yang kini mengklaim wilayah Sendi adalah wilayah yang dikuasai oleh mereka. Desa Sendi sekarang ini menjadi salah satu dari tiga dusun di wilayah Pacet. Masyarakat Desa Sendi yang terbentuk dalam Forum Perjuangan Rakyat mempunyai beberapa bukti yang kuat, selain makam para leluhur mereka, yaitu

1. Kesaksian dan penyataan para orang tua di desa Sendi yang masih hidup hingga sekarang.

2. Peta Sendi apda tahun 1915 yang dirubah tahun 1936.

3. Penelusuran melalui Kantor Pelayanan Pajak Mojokerto tahun 1993, yang menjelaskan bahwa ada 30 Subjek Wajib Pajak untuk tanah Desa Sendi dengan kode 07, Kecamatan Pacet, Kabupaten Mojokerto, sebagaimana catatan tersebut tersusun dalam daftar himpunan ketetapan dan pembayaran pajak hak ata tanah.

4. Pengakuan Pemerintah Desa Pacet yang menyebutkan tentang keberadaan tanah ganjaran Desa Sendi yang dikelola oleh Pemerintah Desa Pacet, Kecamatan Pacet, Kabupaten Mojokerto.

Masyarakat Adat Desa Sendi memberikan kesaksian bahwa tanah Desa Sendi adalah tanah hak milik adat mereka yang pada tahun 1942 dikarenakan adanya Agresi Militer Belanda menyerang Penduduk Desa Sendi, terpaka ditinggalkan oleh mereka untuk melakukan pengungsian di daerah-daerah di bawahnya. Setelah peperangan usai, Kepala Desa Singo Setro menjual tanah pribadi miliknya tetapi bukan tanah milik penduduk Desa Sendi. Namun, pada tahun 1949, wilayah Desa Sendi telah dikuasai oleh Jawatan Kehutanan dengan dimanfaatkan untuk tanaman kayu waru, salaman, abasia, dan sono. Kesuburan tanah Desa Sendi rupanya menarik perhatian Pemerintah Daerah Mojokerto yang 
pada tahu 1965 memberikan tawaran pertukaran lahan Penduduk Desa Sendi dengan daerah di Bandulan, tetapi Penduduk Desa Sendi menolak dengan tegas.

Pada tahun 1999, wilayah Desa Sendi yang semula pohon-pohon pinus ditebang dan ditanami dengan tanaman umur pendek oleh Pihak Perhutani, yang mengklaim wilayah Sendi dikuasai oleh Perhutani berdasarkan Berita Acara Tukar Menukar dan Pemberian Ganti Rugi B nomor 1 - 1931 tanggal 21 November 1931 dan B nomor 3 - 1932 tanggal 10 Oktober 1932, dimana dalam berita acara tersebut terjadi pembebasan tanah oleh Pemerintah Hindia Belanda qq Boschweezen seluas 762,9 Ha khusus untuk Desa Sendi yang telah dibebasklan seluas 72,55 Ha dan yang tidak dibebaskan yaitu seluas 50 Ha. Hal tersebut diterangkan dalam Nota Dinas Sekretaris Pemerintah Kabupaten Mojokerto Nomor 973/2/416-011/2006, tanggal 26 Januari 2005 dan kronologinya dibuat oelh Biro Perencanaan sumebr Daya Hutan, tanggal 26 Januari 2005.

Selama bertahun-tahun, Masyarakat Desa Adat Sendi berjuang untuk memperoleh pengakuannya dan wilayahnya, salah satunya melalui Pemerintah Kabupaten Mojokerto. Sekretaris Daerah Pemerintah Kabupaten Mojokerto menyarakan pada Bupati Mojokerto untuk melibatkan aparat hukum karena menganggap kegiatan penduduk desa sendi adalah perambahan hutan. Sebagaimana tertuang dalam Laporan tanggal 02 Maret 2006 No. Pol:SKTL/83/III/2006/Res Mjk) yang selanjutnya disidik sebagi tindak pidana Perambahan hutan. Laporan ini ditujukan oleh warga desa sendi oelh Perhutani ke Kepolisian Resort (Polres) Mojokerto.

Berbagai upaya perdamaian dilakukan oleh Polres Mojokerto, salah satunya dengan emdiasi dan melakukan pengukuran ulang yang dilaksanakan oleh Kodam V Brawijaya. Hasil dari pengukuran tersebut tanah Sendi tersisa 1.09 Ha, begitu yang disampaikan oleh Kasatreskrim Polres Mojokerto dalam acara Sosialisasi Hukum bersama-sama dengan Koramil Mojokerto yang dilakukan di Dusun Pacet Selatan tanggal 10 Desember 2007. Hasil dalam sosialisasi hukum ini, Polres Mojokerto dan Koramil memberikan peringatan kepada Penduduk Desa Sendi untuk mengosongkan lahan sengketa dengan membongkar rumah 
mereka dalam waktu 10 hari. Meski dalam kenyataannya, sampai saat ini, masih banyak dan bertambah banyak rumah-rumah di wilayah Sendi.

Sehubungan dengan hal-hal tersebut diatas, penulis menganggap sangat penting untuk melakukan penelitian mengenai "ASPEK HUKUM TERHADAP PENYELESAIAN SENGKETA BATAS WILAYAH DESA SENDI " di Kabupaten Mojokerto

\section{METODE}

Penelitian ini menggunakan jenis penelitian yuridis empiris, yaitu suatu pendekatan yang mengacu pada peraturan-peraturan tertulis atau bahan-bahan hukum lainnya yang bersifat sekunder, untuk melihat bagaimana penerapan/pelaksanaannya melalui suatu penelitian lapangan yang dilakukan dengan sosiologis dan wawancara, sehingga diperoleh kejelasan tentang hal yang diteliti $^{10}$.

Metode pendekatan di atas digunakan karena permasalahan yang diteliti berhubungan dengan bagaimana penguasaan masyarakat terhadap sebidang tanah dan terhadap cara penyelesaian sengketa pertanahan yang terjadi, juga mencakup bidang yuridis yaitu peraturan-peraturan perundangan yang mengatur cara pelaksanaannya dan penyelesaian sengketa yang timbul. Dan bagaimana peran pemerintah dalam penyelesaian konflik tersebut ${ }^{11}$

\section{HASIL DAN DISKUSI}

Desa Sendi atau diartikan "Desa yang Hilang" secara histori diyakini sebagai tempat pertapaan para pembesar dan begawan kerajaan Majapahit pada masanya.

Saat ini eks Desa Sendi dikenal oleh penduduk sekitar sebagai Ngeprih-Ngoetan. Secara administrasi pemerintahan, Sendi juga telah eksis sejak tahun 1951. Saat itu Desa Sendi diresmikan oleh Gouverment Oost-Java, Resident Soerabaja, Regentschap 2010).

10 Mohammad Koesnoe, Dasar Dan Metode Ilmu Hukum Positif (Airlangga University Press,

11 Mohammad Koesnoe, Catatan-Catatan Terhadap Hukum Adat Dewasa Ini (Airlangga University Press, 1979). 
Modjokerto, District Djaboeng, Desa Sendi, Oorspronkelijk Opgenomen 1951, yaitu perwakilan pemerintahan Belanda yang berpusat di Surabaya.

Pada zaman penjajahan Belanda, sekitar tahun 1912, Sendi merupakan sebuah desa yang lengkap dengan aparat pemerintahannya. Sendi kala itu menjadi salah satu desa di wilayah Distrik Djaboeng, Regentschap Mojokerto, Recidentie Soerabaja. Berdasarkan keterangan para saksi hidup, luas wilayahnya mencapai 212 hektare.

Menurut cerita turun-temurun, Desa Sendi ada sejak tahun 1600 masehi. Eksistensi Desa Sendi juga dibuktikan dengan dokumen kretek atau buku teritorial Desa Sendi yang dikeluarkan pemerintah kolonial Belanda tahun 1915. Dokumen tersebut menyebutkan luas Desa Sendi 68 hektare.

Selain itu, keberadaan Desa Sendi juga dibuktikan dengan adanya tanah ganjaran para perangkat Desa Sendi seluas 6 hektare. Tanah tersebut tercatat dalam lansiran buku C Desa Pacet tahun 1975. Oleh pemerintah, pengelolaan lahan tersebut sampai saat ini dititipkan di Desa Pacet dan disebut sebagai tanah ganjaran eks Desa Sendi ${ }^{12}$. Akan tetapi nama Desa Sendi sendiri lenyap dari wilayah Administrasi Kabupaten Mojokerto. Di dalam Permendagri No 56 Tahun 2015 tentang Kode dan Data Wilayah Administrasi Pemerintahan, nama Sendi tak termasuk dalam 299 desa dan 5 kelurahan di Kabupaten Mojokerto. Wilayah eks Desa Sendi juga tidak menjadi bagian desa lainnya.

Upaya Pemkab Mojokerto dan masyarakat membentuk Sendi menjadi sebuah desa yang diakui menemui jalan buntu. Penyebabnya, jumlah penduduk Sendi tak memenuhi syarat. Pengajuan Sendi menjadi sebuah desa ditolak oleh Pemprov Jatim. Alasannya, jumlah penduduk Sendi dianggap tak memenuhi syarat minimal untuk menjadi sebuah desa baru. Persyaratan tersebut, diatur dalam UU RI No 6 tahun 2014 tentang Desa ${ }^{13}$. Jumlah minimal penduduk agar bisa diakui sebagai desa adalah 6.000 jiwa, sementara jumlah penduduk Sendi saat diusulkan tak sampai 6000 jiwa. Pengajuan Sendi menjadi desa adat ditolak oleh Pemprov Jatim dan tidak diberi kode register desa. Provinsi sudah konsultasi ke Kemendagri, persyaratan jumlah penduduk minimal 6 ribu itu sudah mutlak.

12 Ahmad Heru Romadhon et al., "Dinamika Pranata Pemerintahan Desa Adat Dalam Dimensi Hukum Tata Negara," Jurnal Hukum Media Bhakti 2, no. 2 (2018): 127-137.

13 Saifatul Husna and Syukriy Abdullah, "Kesiapan Aparatur Desa Dalam Pelaksanaan Pengelolaan Keuangan Desa Secara Akuntabilitas Sesuai Undang-Undang Nomor 6 Tahun 2014 Tentang Desa (Studi Pada Beberapa Desa Di Kabupaten Pidie)," Jurnal Ilmiah Mahasiswa Ekonomi Akuntansi 1, no. 1 (2016): 282-293. 
Pengakuan keberadaan masyarakat hukum adat berdasarkan Pasal 18B UUD 1945 menjadi pedoman pengakuan sekaligus bentuk perlindungan hukum atas keberadaan masyarakat hukum adat di Indonesia $^{14}$. Pengakuan yang dimaksud adalah bahwa masyarakat hukum adat diakui dan dilindungi sebagai subjek hukum dan hak-hak tradisionilnya. Secara faktual, wujud pengakuan tersebut ditemukan dalam berbagai kegiatan pemerintahan terutama aktivitas yang berkaitan dengan keberadaan masyarakat hukum adat ${ }^{15}$.

Dengan adanya UU No. 6 Tahun 2014 tentang Desa mengatur kewenangan pemerintahan Desa. pasal 18 UU No. 6 Tahun 2014 tentang Desa, mengatur tentang klasifikasi bidang dalam pemerintahan Desa $^{16}$. adapun bidang tersebut yakni penyelenggaraan pemerintahan desa, pelaksanaan pembangunan desa, pembinaan kemasyarakatan desa dan pemberdayaan masyarakat desa berdasarkan prakarsa masyarakat hukum adat setempat, hak asal usul dan adat istiadat desa ${ }^{17}$. Peraturan Menteri Dalam Negeri Republik Indonesia Nomor 1 Tahun 2017 Tentang Penataan Desa Pasal 8 ayat (1) berbunyi "Pemerintah Pusat dapat memprakarsai pembentukan Desa di kawasan yang bersifat khusus dan strategis bagi kepentingan nasional, tanpa memperhatikan persyaratan pembentukan Desa ${ }^{18}$.

Bagi masyarakat hukum adat, tanah mempunyai kedudukan yang sangat penting dalam melangsungkan hidup. Sifatnya, bahwa tanah merupakan benda kekayaan yang meskipun mengalami keadaan yang bagaimanapun juga akan tetapi masih bersifat tetap dalam keadaannya bahkan kadang menjadi lebih menguntungkan. Faktanya bahwa tanah merupakan tempat tinggal warga masyarakat hukum adat setempat, tanah juga memberikan penghidupan kepada persekutuan (masyarakat), tempat di mana para warga persekutuan yang meninggal dikuburkan, serta merupakan tempat tinggal bagi dayangdayang pelindung persekutuan dan roh-roh para leluhur ${ }^{19}$.

14 Lalu Sabardi, "Konstruksi Makna Yuridis Masyarakat Hukum Adat Dalam Pasal 18B UUDN RI Tahun 1945 Untuk Identifikasi Adanya Masyarakat Hukum Adat," Jurnal Hukum \& Pembangunan 44, no. 2 (2014): 170-196.

15 Safrin Salam, "Perlindungan Hukum Masyarakat Hukum Adat Atas Hutan Adat," Jurnal Hukum Novelty 7, no. 2 (2016): 209-224.

16 Undang-Undang No, "Tahun 2014 Tentang Desa," Penerbit Sinar Garafika Jakarta (6AD).

17 Arif Zainudin, "Model Kelembagaan Pemerintahan Desa," Jurnal Ilmu Pemerintahan: Kajian Ilmu Pemerintahan Dan Politik Daerah 1, no. 2 (2016): 332-339.

18 Peraturan Menteri Dalam Negeri Nomor, “Tahun 2017 Tentang Penataan Desa," Republik Indonesia (1AD).

19 Tolib Setiady, Intisari Hukum Adat Indonesia Dalam Kajian Kepustakaan (Alfabeta, 2008). 
Peraturan Dalam Negeri (Permendagri) No. 56 Tahun $2015^{20}$ tentang Kode dan

Data Wilayah Administrasi Pemerintahan, nama Sendi tidak lagi termasuk dalam 299 desa dan 5 kelurahan di Kabupaten Mojokerto menimbulkan kegelisahan masyarakat adat setempat. Dengan kata lain tanah merupakan salah satu sumber daya alam yang sangat dekat dengan hak individu, dimana setiap individu membutuhkan tanah tersebut guna memenuhi kebutuhan pokok, baik membangun tempat berlindung, mengelola lahan untuk mencari penghasilan dan lain sebagainya.

Aspirasi masyarakat hukum adat menginginkan pemerintah meninjau kembali dengan memperhatikan adanya TAP MPR Nomor XVII tahun 1998 tentang Hak Asasi Manusia, maka hak pemajuan dan perlindungan keberadaan masyarakat hukum adat termasuk di dalamnya tanah ulayat telah diakomodir, (pasal 30,31 dan 42) yang selanjutnya dapat dijadikan acuan dalam menyelesaikan konflik atas batas wilayah masyarakat hukum adat di kawasan hutan agar kelestarian hutan dapat tercapai.

Terlebih lagi dengan terbitnya Undang-Undang Pemerintah Daerah No. 22 tahun 1999, Peraturan Menteri Agraria/Kepala BPN No. 5 tahun 1999 tentang Pedoman Penyelesaian Masalah Hak Ulayat Masyarakat Hukum Adat demikian pula dengan terbitnya Undang-Undang Kehutanan yang baru No. 41 tahun 1999 semakin jelas bahwa pengakuan hak-hak masyarakat hukum adat dapat segera dilakukan di daerah masing-masing dan diharapkan bukan hanya pengakuan yang memberikan kepastian hukum tetapi juga diikuti dengan pemulihan hak-haknya ${ }^{21}$.

Berdasarkan TAP IX/MPR/2001 tersebut yang menghendaki pengakuan, penghormatan, dan perlindungan hak masyarakat hukum adat ${ }^{22}$. Penulis menggaris bawahi bahwa ketentuan di atas menunjukan bahwa Hak Ulayat harus benar-benar masih ada dan tidak diberikan peluang untuk menimbulkan kembali hak-hak tersebut, jika secara faktual dalam masyarakat sudah tidak ada lagi. Namun ketentuan di atas tidak memberikan syarat untuk menunjukan masih ada atau tidaknya Hak Ulayat suatu masyarakat hukum adat. Keberadaan Hak Ulayat harus diikuti dengan hubungan antara

20 Peraturan Menteri Dalam Negeri R I Nomor, "Tahun 2015 Tentang Kode Dan Data Wilayah Administrasi Pemerintahan" (56AD).

21 Peraturan Menteri Negara Agraria and Kepala Badan Pertanahan Nasional Nomor, "Tahun 1999 Tentang Pedoman Penyelesaian Masalah Hak Ulayat Masyarakat Hukum Adat," 5AD.

22 Yanis Maladi, "Eksistensi Hukum Adat Dalam Konstitusi Negara Pasca Amandemen," Mimbar Hukum-Fakultas Hukum Universitas Gadjah Mada 22, no. 3 (2010): 450-464. 
tanah dan masyarakat. Dengan demikian selama tanah ulayat tersebut ada, haruslah dimanfaatkan oleh warga masyarakat guna meningkatkan kesejahteraan ${ }^{23}$.

\section{KESIMPULAN}

Perjalanan untuk memperjuangkan desa Sendi menjadi desa adat, mengalami berbagai benturan, baik secara administrasi maupun syarat kependudukan. Hal ini menjadi problematika sendiri. Karena desa Sendi memiliki berbagai macam kekayaan berupa kearifan budaya local. Sehingga ini memicu perjuangan berlanjut hingga saat ini. Ada kemungkinan untuk menjadikan desa Sendi menjadi desa adat. Tentunya harus melewati serangkaian proses yang memerlukan waktu yang cukup panjang

\section{SARAN}

Perlunya koordinasi dari berbagai pihak, baik masyarakat, pemerintah yang terkait, sampai kepada pemangku kebijakan untuk bersinergi dalam rangika memperjuangkan desa Sendi menjadi desa adat. Mengingat ada beberapa daerah yang mengalami kasus yang sama. Political will diharapkan mampu mewujudkan cita-cita tersebut, sehingga Desa sendi tidak menjadi desa yang "hilang".

\section{DAFTAR BACAAN}

Agraria, Peraturan Menteri Negara, and Kepala Badan Pertanahan Nasional Nomor. "Tahun 1999 Tentang Pedoman Penyelesaian Masalah Hak Ulayat Masyarakat Hukum Adat," 5AD.

Husna, Saifatul, and Syukriy Abdullah. "Kesiapan Aparatur Desa Dalam Pelaksanaan Pengelolaan Keuangan Desa Secara Akuntabilitas Sesuai Undang-Undang Nomor 6 Tahun 2014 Tentang Desa (Studi Pada Beberapa Desa Di Kabupaten Pidie).” Jurnal Ilmiah Mahasiswa Ekonomi Akuntansi 1, no. 1 (2016): 282-293.

Indonesia, PRESIDEN REPUBLIK, and Presiden Republik Indonesia. Undang-Undang No. 5 Tahun 1960

23 Mahrita Aprilya Lakburlawal, "Akses Keadilan Bagi Masyarakat Adat Dalam Penyelesaian Sengketa Tanah Ulayat Yang Diberikan Hak Guna Usaha," Jurnal Hukum Acara Perdata ADHAPER 2, no. 1 (2016): 59-75. 
Tentang Peraturan Dasar Pokok-Pokok Agraria. Ganung Lawu, 1960.

Koesnoe, Mohammad. Catatan-Catatan Terhadap Hukum Adat Dewasa Ini. Airlangga University Press, 1979.

—_. Dasar Dan Metode Ilmu Hukum Positif. Airlangga University Press, 2010.

Lakburlawal, Mahrita Aprilya. “Akses Keadilan Bagi Masyarakat Adat Dalam Penyelesaian Sengketa Tanah Ulayat Yang Diberikan Hak Guna Usaha.” Jurnal Hukum Acara Perdata ADHAPER 2, no. 1 (2016): 59-75.

Maladi, Yanis. "Eksistensi Hukum Adat Dalam Konstitusi Negara Pasca Amandemen.” Mimbar HukumFakultas Hukum Universitas Gadjah Mada 22, no. 3 (2010): 450-464.

No, Undang-Undang. “Tahun 2014 Tentang Desa.” Penerbit Sinar Garafika Jakarta (6AD).

Nomor, Peraturan Menteri Dalam Negeri. "Tahun 2017 Tentang Penataan Desa.” Republik Indonesia (1AD).

Nomor, Peraturan Menteri Dalam Negeri R I. "Tahun 2015 Tentang Kode Dan Data Wilayah Administrasi Pemerintahan" (56AD).

Nomor, Undang-Undang. “Tahun 1960 Tentang Peraturan Dasar Pokok-Pokok Agraria.” Jakarta: portal. djmbp. esdm. go. id (diunduh 4 Nopember 2011) (5AD).

—_. "Tahun 1999 Tentang Kehutanan.” Penerbit PT. Mitra Info, Jakarta (41AD).

Rachman, Noer Fauzi. "Masyarakat Hukum Adat Adalah Bukan Penyandang Hak, Bukan Subjek Hukum, Dan Bukan Pemilik Wilayah Adatnya." Wacana 33 (2014): 25-50.

Romadhon, Ahmad Heru, Isnin Harianti, Nabilah Royhana, and Melisa Agustina. "Dinamika Pranata Pemerintahan Desa Adat Dalam Dimensi Hukum Tata Negara.” Jurnal Hukum Media Bhakti 2, no. 2 (2018): 127-137.

Sabardi, Lalu. "Konstruksi Makna Yuridis Masyarakat Hukum Adat Dalam Pasal 18B UUDN RI Tahun 1945 Untuk Identifikasi Adanya Masyarakat Hukum Adat.” Jurnal Hukum \& Pembangunan 44, no. 2 (2014): 170-196.

Salam, Safrin. "Perlindungan Hukum Masyarakat Hukum Adat Atas Hutan Adat." Jurnal Hukum Novelty 7, no. 2 (2016): 209-224.

Sari, Daisyta Mega, and Akhyaroni Fu'adah. "Peran Pemerintah Daerah Terhadap Perlindungan Hutan 
Adat Pasca Putusan Mahkamah Konstitusi Nomor 35/Puu-x/2012." Jurnal Penelitian HukumFakultas Hukum Universitas Gadjah Mada 1, no. 1 (2014): 53-61.

Setiady, Tolib. Intisari Hukum Adat Indonesia Dalam Kajian Kepustakaan. Alfabeta, 2008.

Soetomo. Politik Dan Administrasi Di Bidang Agraria. Departemen Pendidikan dan Kebudayaan, Universitas Brawijaya, Fakultas Hukum, 1985.

Yusuf, Abdul Muis, and Muhammad Taufik Makarao. Hukum Kehutanan Di Indonesia. Rineka Cipta, 2011.

Zainudin, Arif. "Model Kelembagaan Pemerintahan Desa." Jurnal Ilmu Pemerintahan: Kajian Ilmu Pemerintahan Dan Politik Daerah 1, no. 2 (2016): 332-339.

Zakaria, R Yando. "Strategi Pengakuan Dan Perlindungan Hak-Hak Masyarakat (Hukum) Adat: Sebuah Pendekatan Sosio-Antropologis.” BHUMI: Jurnal Agraria dan Pertanahan 2, no. 2 (2018): 133-150. 